\title{
Relasi Kuasa dalam Perebutan Lahan di Situs Candi Bojongmenje
}

\author{
Fikri Muhammad dan Caroline Paskarina \\ Program Studi Ilmu Politik, FISIP Universitas Padjadjaran \\ fikrimuh.barlian@gmail.com
}

\begin{abstract}
This paper discusses the power relations in the land dispute on the site of Bojongmenje Temple, to reveal why conflicts in Bojongmenje Temple Site lasted continuously (2003-present). To clarify this, this paper uses an analysis of power relations to identify the mutually contested interests in establishing a claim on land in the site of Bojongmende Temple area. The research method used is qualitative method, with data collection through indepth interview among actors involved in conflict. The research finds that land dispute in the area of Bojongmenje Temple site is a complicated conflict, preceeded by changes in the economic value of land due to the discovery of cultural heritage sites that have tourism potential. This complicated conflict is prolonged and unresolved because the government's bargaining power as an authoritative institution is in a weak position. Conflict resolution needs to be arranged comprehensively, especially to resolve the root of conflict triggered by the instability of system change. This is done by balancing the power positions among conflicting actors in the land management of the Bojongmenje Temple site, beginning with the recognition of local land rights by the government and establishing concensus with citizens to manage the site participatively.
\end{abstract}

Keywords: power relations, conflict, land dispute

\begin{abstract}
Abstrak
Tulisan ini membahas tentang relasi kuasa dalam perebutan lahan di situs Candi Bojongmenje untuk mengungkapkan mengapa konflik dalam perebutan lahan di Situs Candi Bojongmenje berlangsung dengan lama (2003-sekarang). Untuk menjelaskan hal tersebut, tulisan ini menggunakan analisis kekuasaan untuk mengidentifikasi ragam kepentingan yang saling berkontestasi untuk membentuk klaim atas lahan di kawasan Situs Candi Bojongmende. Metode penelitian yang digunakan adalah metode kualitatif, dengan pengumpulan data melalui wawancara mendalam kepada para aktor yang terlibat di dalam konflik. Hasil riset menemukan bahwa konflik lahan di kawasan situs Candi Bojongmenje merupakan bentuk konflik pelik, yang diawali oleh perubahan nilai ekonomi lahan akibat ditemukannya situs cagar budaya yang berpotensi wisata. Konflik pelik ini berlangsung berkepanjangan dan tidak terselesaikan karena posisi tawar pemerintah sebagai institusi yang memegang otoritas justru berada pada posisi yang lemah. Penyelesaian konflik pelik perlu dilakukan secara komprehensif, terutama untuk menyelesaikan akar permasalahan yang dipicu akibat dari ketidakstabilan perubahan. Hal tersebut dilakukan dengan menyeimbangkan posisi kekuasaan dari para aktor yang berkepentingan di dalam pengelolaan lahan situs Candi Bojongmenje, yang diawali dengan pengakuan hak atas tanah dari warga setempat oleh pemerintah dan membangun kesepakatan dengan warga mengenai rencana pengelolaan kawasan tersebut secara partisipatif.
\end{abstract}

Kata kunci: relasi kuasa, konflik pelik, perebutan lahan

\section{Pendahuluan}

Penguasaan lahan masih menjadi isu penting, khususnya di negara-negara yang masih menitikberatkan pertumbuhan ekonominya pada sumber daya alam. Lahan memiliki nilai strategis karena tidak hanya menunjukkan kepemilikan akan sumber daya ekonomi, 
tetapi juga menjadi simbol status sosial dan politik dalam masyarakat. Oleh karena itu, penguasaan lahan seringkali bersinggungan dengan berbagai kepentingan politik, bahkan tidak jarang berujung pada timbulnya konflik yang berkepanjangan.

Konflik tersebut mudah muncul ketika lahan yang diperebutkan mempunyai nilai jual tinggi sehingga pihak yang memperebutkan bersaing untuk mendapatkannya. Pihak yang berkonflik berupaya membangun klaim yang menjustifikasi haknya atas lahan, bisa dengan menggunakan bukti-bukti hukum atau dengan dasar status sosial-ekonomi. Berbagai klaim yang muncul dalam konflik lahan menunjukkan bahwa yang diperebutkan bukan hanya lahan sebagai obyek material, tetapi juga legitimasi atas penguasaan lahan tersebut. Kuasa atas lahan itulah yang menyebabkan konflik lahan dan berbagai sumber agraria lainnya berlangsung dengan sangat ketat, struktural, dan berkepanjangan bahkan sulit terselesaikan karena akar masalahnya bukan pada ganti rugi material, melainkan pada relasi kuasa yang memberikan justifikasi kepada pihak tertentu untuk mengatur pengelolaan lahan bahkan mengatur pula kedudukan pihak-pihak lainnya atas lahan tersebut.

Konteks kekuasaan yang bersinggungan dengan faktor ekonomi sebagai pemicu konflik lahan diungkapkan oleh Acep Supriadi Wahyu dan Mariatul Kiptiah (2016) ketika menjelaskan penyebab terjadinya konflik di Kecamatan Gambut, Kalimantan Selatan. Konflik ini terjadi ketika warga menemukan adanya sertifikat berlapis yang diterbitkan atas tanah di wilayah tersebut. Kasus ini baru muncul ketika dibuka akses jalan ke wilayah tersebut sehingga mengubah nilai ekonomi tanah di sana yang semula hanya lahan tidur atau bisa disebut juga Hutan Galam. Konflik ini diselesaikan dengan pendekatan non litigasi, melalui pemberian komisi sesuai dengan kesepakatan antara pihak yang berkepentingan. Riset tersebut menyajikan temuan menarik tentang makna baru uang dalam penyelesaian konflik. Uang yang diberikan tersebut bukanlah sebagai pengganti dari kerugian material, tetapi sebagai pengakuan akan kuasa kepemilikan atas sumber daya tanah tersebut.

Konflik lahan juga seringkali memperhadapkan negara dengan masyarakat, seperti yang diungkapkan oleh Maring (2013). Dalam penelitiannya yang berjudul "Kekuasaan dan Konflik Sosial: Kasus Penguasaan Hutan Noge di Tanaloran Flores" dijelaskan adanya pembatasan lahan yang ditetapkan pada tahun 1984 oleh Departemen Kehutanan melalui mekanisme Tata Guna Hutan Kesepakatan (TGHK). Berdasarkan mekanisme tersebut pemerintah memiliki kewenangan yang besar untuk menentukan batasan kepemilikan lahan, bahkan riset tersebut menemukan bahwa lahan yang tadinya milik masyarakat pada tata batas tahun 1932, yang ditetapkan pada zaman kolonial Belanda, justru diambil oleh petugas lapangan kehutanan (mantri hutan). Praktik kekuasaan mewujud pada cara yang digunakan oleh petugas untuk menentukan batasan lahan. Petugas mematok lahan dengan cara menaiki kuda, kemudian kuda itu dibiarkan berjalan mengelilingi lahan, dan ketika petugas dan kuda itu kelelahan, maka disitulah letaknya batas pal lahan. Akibatnya, lahan yang semula dimiliki oleh masyarakat sesuai tata batas tahun 1932 diklaim sebagai kawasan hutan.

Praktik kekuasaan yang ditunjukkan aparat pemerintah tersebut memicu perlawanan dari masyarakat lokal untuk mendapatkan distribusi sumber daya secara adil dan kepastian hak akses (hak milik). Perlawanan dari masyarakat dilakukan dengan secara terbuka, antara lain dengan menduduki areal lahan, melakukan penyekapan, demonstrasi, bahkan perkelahian fisik. Semua dilakukan untuk mematahkan dominasi kekuasaan pemerintah atas hutan demi untuk mendapatkan distribusi sumber daya hutan secara adil dan mendapatkan kepastian hak milik (Maring, 2013).

Berbagai kasus di atas menggambarkan bagaimana lahan, konflik, dan kuasa sebenarnya saling berkaitan. Adapun tulisan ini ingin mengungkapkan relasi kuasa di balik perebutan lahan Situs Candi Bojongmenje. 
Situs candi peninggalan agama Hindu ini merupakan salahsatu candi yang ditemukan di kawasan Jawa Barat pada 18 Agustus 2002, tepatnya di Kampung Bojongmenje, Desa Cangkuang, Kecamatan Rancaekek. Asal-usul nama Candi Bojongmenje disesuaikan dengan nama kampung tempat candi itu ditemukan. Untuk memasuki kawasan candi dari jalan raya harus melalui lorong gang yang panjangnya sekitar 125 meter dan lebar 2 meter (Sobari, et al., 2012).

Penemuan candi membuka peluang untuk menjadi destinasi wisata karena melihat umur candi yang lebih tua dari Candi Borobudur yaitu abad ke 7 Masehi. Penemuan candi itu lantas ditindaklanjuti oleh Dinas Pariwisata dan Kebudayaan Provinsi Jawa Barat bersama Balai Arkeologi Bandung sebagai unit pelaksanaan teknis dari Pusat Penelitian Arkeologi Nasional dan Balai Pelestarian Cagar Budaya Serang. Ketiganya bersama-sama melakukan berbagai kegiatan meliputi perlindungan, penelitian, dan pemugaran di kawasan candi tersebut.

Setelah penemuan situs tersebut, tanah di sekitar kawasan yang tadinya merupakan pemakaman umum berubah menjadi tanah yang mempunyai harga jual yang tinggi berkat penemuan Candi Bojongmenje. Pada tahun 2003, beberapa orang dari Dinas Pariwisata dan Kebudayaan Provinsi Jawa Barat berinisiasi membuat tim pembebasan lahan. Di dalam dokumen Berita Acara Musyawarah Penetapan Besarnya Ganti Rugi/Transaksi Harga Tanah untuk Kepentingan Kegiatan Pembinaan dan Pelestarian Peninggalan Sejarah dan Purbakala Jawa Barat Tahun Anggaran 2003 berdasarkan SK Gubernur 910/kep.189-Dalprog/2003, tertulis bahwa tim tersebut terdiri dari Drs. Daryat sebagai Pemimpin Kegiatan Pembinaan dan Pelestarian Peninggalan Sejarah dan Purbakala Jawa Barat Tahun 2003 dan Drs. Eddy Sunarto sebagai Kepala Seksi Pengembangan Budaya Daerah, Subdin Kebudayaan, Disbudpar Jawa Barat (Sunarto \& Daryat, 2003). Pembentukan tim ini disahkan oleh Bupati Bandung tahun $2003 \mathrm{H}$. Obar Sobarna, S.IP. melalui surat keputusan persetujuan penetapan lokasi pengembangan situs Candi Bojongmenje. Tugasnya ialah membebaskan lahan, meng-amankan, dan mensertifikasi tanah atas nama Pemerintah Jawa Barat. Pelestarian Candi Bojongmenje merupakan hal yang penting karena memiliki nilai sejarah, ilmu pengetahuan, agama, dan kebudayaan yang tinggi sesuai dengan Undang-Undang Cagar Budaya tahun 2010 pada pasal 1 ayat 1 . Dalam Peraturan Daerah Provinsi Jawa Barat Nomor 16 Tahun 2014 juga disebutkan mengenai pembentukan tim ahli oleh dinas serta melakukan upaya perlindungan, pengembangan, dan pemanfaatan atas cagar budaya sesuai yang tertera pada Pasal 6. Tetapi, hal itu tidaklah mudah karena Pemerintah Provinsi harus membongkar kuburan masyarakat setempat yang sudah lama berada di lahan tersebut. Selain itu, Pemerintah Provinsi juga harus membebaskan lahan lokasi di-temukannya Situs Candi Bojongmenje sedangkan areal sekitarnya adalah pabrik dan pemukiman, sehingga tidak mudah dikosongkan.

Perubahan itulah yang kemudian memicu munculnya konflik antara Pemerintah Provinsi Jawa Barat, yang berkepentingan untuk mempertahankan situs candi, dengan warga setempat yang ingin mempertahankan kepe-milikan atas lahan di kawasan situs. Catatan Sunarto (2016) tentang proses pembebasan lahan Situs Candi Bojongmenje, mengungkapkan bagaimana asal mula kemunculan konflik, sebagai berikut:

"Pada awal mula pemerintah yang diwakili tim pembebasan lahan berinisiasi untuk memberikan lahan pengganti untuk pemakaman umum kepada sanak keluarga dari mendiang mereka. Tetapi, ide tersebut ditolak, mereka lebih setuju lahan yang menjadi tanah kubur digantirugikan dengan uang. Dari sanalah putusan musyawarah dilakukan sehingga membebaskan lahan yang berukuran $532 \mathrm{~m}^{2}$ dari $845 \mathrm{~m}^{2}$. Tetapi, hal ini ternyata tidak menyelesaikan konflik karena masih tersisa lahan seluas 313 $\mathrm{m}^{2}$ yang diakui sebagai milik seorang warga setempat (Anen Zulkarnaen). 
Ia merasa orangtuanya tidak pernah mewakafkan tanah tersebut menjadi pemakaman umum. Lalu, pemerintah berinisiatif untuk membeli lahan yang dimilikinya. Negosiasi pun selesai dengan keputusan final Anen meminta Rp.1.500.000/m². Pemerintah tidak bisa menyetujui harga tersebut karena tidak sesuai dengan harga tanah menurut Nilai Jual Objek Pajak dan Bumi (NJOP) pada tahun 2003 karena NJOP di lahan Situs Candi Bojongmenje berjumlah Rp.64.000/ $\mathrm{m}^{2}$. Hasil nego-siasi pun terhenti sampai disitu”.

Hal inilah pemicu terjadinya konflik. Pihak pemerintah dan Anen sama-sama bersikeras atas kepentingan masing-masing. Akibatnya upaya pemugaran Situs Candi Bojongmenje terhenti sampai sekarang.

Tulisan ini ingin mengungkapkan mengapa konflik dalam perebutan lahan di Situs Candi Bojongmenje berlangsung dengan lama (2003-sekarang). Untuk menjelaskan hal tersebut, tulisan ini menggunakan analisis kekuasaan untuk mengidentifikasi ragam kepentingan yang saling berkontestasi untuk membentuk klaim atas lahan di kawasan Situs Candi Bojongmende.

\section{Kajian Pustaka}

Studi tentang relasi kekuasaan dalam konteks perdesaan umumnya melihat relasi tersebut dalam hubungan yang bersifat patronase, misalnya antara tuan tanah dan petani kecil (Scott, 1981), yang kemudian juga mewujud dalam bentuk relasi transaksional melalui praktik politik uang dalam pemilihan kepala desa (Maftuchin, 2016). Karakter relasi kekuasaan tersebut juga tampak dalam konteks konflik penguasaan lahan, yang dipicu oleh ketimpangan struktural dalam hal penguasaan sumber daya.

Tulisan ini menggunakan konsep konflik pelik untuk menjelaskan mengapa konflik lahan seringkali berlangsung berlarut-larut dan tidak mudah terselesaikan. Konflik pelik adalah suatu keadaan konflik yang bertahan lama, umumnya terjadi antara individu, kelompok, atau Negara. Dalam skala yang lebih luas, konflik pelik cenderung menarik keterlibatan banyak pihak dan permasalahannya menjadi semakin rumit serta menimbulkan ancaman (Deutsch, Coleman, \& Marcus, 2006). Azar (1990) menjabarkan beberapa penyebab yang mengubah suatu situasi non-konfliktual ke zona konfliktual. Pertama, masyarakat yang dicirikan memiliki komposisi multikomunal, apakah itu dibentuk dari kekuatan kolonial sebelumnya atau melalui persaingan historis yang sering mengakibatkan persaingan dominasi kelompok diatas yang lain. Kedua, kebutuhan manusia, dalam hal ini, kebutuhan kelangsungan hidup dan kesejahteraan fisik. Suatu kelompok atau individu dapat berkonflik karena kebutuhan ekonomi. Hal serupa juga dinyatakan oleh Diehl dan Goertz yang menyebut nama lain dari konflik pelik yaitu persaingan abadi (1993) menurut mereka dasar terjadinya konflik pelik adalah adanya persaingan atas barang tak berwujud (prestige, pengaruh) atau barang nyata (wilayah, sumberdaya).

Terakhir, nama lain dari konflik pelik adalah konflik yang berakar kuat (Burton, 1987). Tidak lagi berbicara mengenai definisi dari konflik pelik, Burton justru memberikan teknik penyelesaiannya. Pertama, mengubah persepsi pihak yang berkonflik terhadap orang-orang yang mereka hadapi. Kedua, mengenali sentralitas kebutuhan manusia yang frustasi karena konflik. Ketiga, mencoba berpikir tentang hubungan yang positif. Keempat, memulai proses generasi yang menantang konflik yang sebelumnya terjadi agar para aktor baru tersebut dapat mengubah hubungan mereka kearah yang lebih damai.

Konflik pelik ditandai oleh sejumlah karakteristik (Deutsch, 1973). Pertama, ketidakstabilan. Ketika suatu keadaan menyebabkan perubahan besar, ia dapat menghancurkan stabilitas dan menyebabkan gangguan besar dalam sistem, sehingga konflik dapat muncul ke permukaan karena pergeseran dalam keseimbangan (atau ketidakseimbangan) 
kekuasaan antara pihak yang bersengketa (Pruitt \& Olczak, 2004).

Kedua, menyebarnya isu yang memicu konflik. Sebuah isu yang menyebar yang muncul akibat kebutuhan manusia, kecenderungan, prinsip, atau proses yang bertentangan, akan melahirkan reaksi yang paradoks untuk memecahkannya, seperti perilaku dilema atas perubahan dan stabilitas, interdependensi dan keamanan, pengambilan keputusan inklusif dan efisien, serta hak individu dan kelompok (Coleman, 2003). Di dalam dilema tersebut terkadang sulit untuk menggabungkan gagasan karena tercampur dengan emosi dan keyakinan pribadi.

Ketiga, adanya hubungan yang ekslusif dari dari pihak yang berkonflik. Hubungan yang eksklusif membatasi kontak antar-kelompok dan terisolasi. Kurangnya kontak ini menyebabkan berkembangnya gambaran abstrak, stereotip mengenai pihak lain yang cenderung me-nimbulkan kekerasan antar-kelompok.

Keempat, konflik yang tersebar menyebabkan kompleksitas dan perubahan. Sifat ini berdampak pada penyelesaian konflik. Biasanya dinamika konflik akan selalu berubah seiring kompleksnya suatu konflik. Karakter dari isu konflik, hubungan para pihak, dan intensitas konflik pun akan selalu berubah. Keadaan yang sering berubahubah akan mempengaruhi ketahanan konflik tersebut. Umumnya semakin kompleks permasalahannya akan semakin sulit upaya resolusi. Seperti yang dikatakan oleh Rouhana \& Bar-Tal (1998), efek konflik yang menyebar dan meresap akan memengaruhi berbagai aspek kehidupan sosial dan politik seseorang atau masyarakat.

Kelima, konflik dianggap sebagai hal yang wajar. Menganggap wajar sebuah permusuhan biasanya terjadi karena konflik yang rumit. Permusuhan seperti sikap tak acuh bahkan kekerasan sudah menjadi realitas alamiah. Misalnya, pemuda Israel dan Palestina di Timur Tengah lebih menerima dan membenarkan penggunaan kekerasan dan perang dalam konflik jauh melebihi pemuda
Eropa yang terlibat konflik (Orr, Sagi, \& Bar-On, 2000).

Dalam perebutan lahan jarang ditemukan posisi yang setara, umumnya salah satu pihak mempunyai dominasi yang lebih kuat. Pihak yang mendominasi biasanya melakukan berbagai upaya untuk menciptakan klaim kebenaran. Maka, penting untuk membahas bagaimana sesungguhnya posisi kekuasaan dipertahankan melalui penciptaan klaim kebenaran tersebut. Menurut Gramsci (1973), penciptaan klaim kebenaran dimaksudkan untuk mempertahankan relasi kekuasaan yang hegemonik, di mana penguasa atau pihak-pihak yang dominan menjalankan dan melestarikan kekuasaannya dalam masyarakat melalui konsensus (persetujuan) terhadap yang dikuasai atau didominasi. Dengan demikian, kebudayaan dan masyarakat tidak lain merupakan perwujudan dari upaya-upaya hegemoni yang justru diterima secara konseptual oleh mereka yang terhegemoni. Di dalam konteks hegemonik, proses penguasaan berlangsung canggih dan halus karena menyasar pada kesadarankesadaran yang menentukan pikiran-pikiran, perkataan-perkataan, dan tindakan masyarakat (Bocock, 1986).

Gramsci (1973) berpendapat bahwa kelas penguasa tidak hanya memanfaatkan cara paksa dalam memperoleh kekuasaan tetapi juga menanamkan ideologi dengan cara yang tidak terlihat. Dominasi dipelihara secara halus sehingga dapat diterima oleh kelompok tersubordinasi. Ketika pihak yang dikuasai mematuhi kendali penguasa dan disaat yang sama mereka menyetujui subordinasi atas diri mereka, maka disitulah hegemoni bekerja. Hegemoni mengacu pada kontrol ideologis dan persetujuan yang dihayati dalam struktur nilai, sikap, keyakinan, dan moral. Hal ini bisa saja terjadi dalam perebutan lahan karena pihak yang menghegemoni mempunyai sikap untuk tetap pada kepentingan mempertahankan nilai-nilai tertentu yang diyakininya.

Jika melihat dari latar belakang terjadinya konflik pelik, alasan suatu pihak untuk memelihara relasi kekuasaan hegemonik 
berlatar kepentingan material. Kelompok yang dikuasai menyadari keinginan kelompok dominan tersebut, tetapi pihak ini tidak bisa berbuat banyak dan menyadari akan adanya kuasa yang membatasinya. Seperti yang diungkapkan oleh Setiawan (2016) kelompok masyarakat yang terhegemoni memiliki konsep diri, bergerak, dan bertindak dalam wilayah ciptaan ideologi yang menguasainya. Keadaan tersebut menempatkan ideologi dominan pada posisi status quo.

Di dalam konsep hegemoni Gramsci (dalam Heryanto, 1997), agar kekuasaan dapat abadi dan langgeng membutuhkan paling tidak dua perangkat kerja. Pertama, perangkat kerja yang mampu melakukan tindak kekerasan yang bernuansa law enforcement. Perangkat kerja yang pertama ini biasanya dilakukan oleh negara melalui lembaga-lembaga hukum, militer, polisi, dan bahkan penjara. Kedua, adalah perangkat kerja yang mampu membujuk masyarakat beserta pranatapranata untuk taat kepada mereka yang berkuasa melalui kehidupan beragama, pendidikan, kesenian, dan bahkan juga keluarga (Heryanto, 1997). Situasi ini biasa terjadi dalam suatu konflik apalagi dalam situasi konflik berkepanjangan. Dalam posisi status quo tentu tidak bisa membiarkan kelompok yang tersubordinasi membalikan keadaan. Perlunya dukungan dan bantuan maksimal dari pihak lain sebagai perangkat kerja guna melanggengkan posisi kuasa.

\section{Metode}

Tulisan ini ingin menganalisis penyebab mun-culnya konflik pelik dalam penguasaan lahan di kawasan Situs Candi Bojongmenje. Untuk mengungkapkan penyebabnya, peneliti berupaya menggali, menelaah, dan memahami pandangan, perasaan, serta perilaku individu atau kelompok khususnya mengenai permasalahan perebutan lahan di Situs Candi Bojongmenje. Untuk mendapatkan data tersebut, penelitian ini menggunakan teknik pengumpulan data dengan wawancara dan pengumpulan data dokumen yang berkaitan dengan perebutan lahan di Situs Candi Bojongmenje.
Wawancara mendalam dilakukan terhadap sejumlah informan, yang diawali dengan informan kunci yakni warga setempat yang menemukan situs tersebut. Informan kunci dapat mendeskripsikan pengalaman, perilaku, tindakan, dan kegiatan mengenai permasalahan penelitian. Selain itu, yang terpenting, ia dapat memberikan sumber informasi selanjutnya yang tentunya bisa digali mengenai perebutan lahan di Situs Candi Bojongmenje. Selain itu, data dokumen mengenai studi teknis Candi Bojongmenje akan menjadi data dokumen utama. Sementara, data dokumen yang bentuknya seperti perjanjian negosiasi harga tanah atau data yang tidak memberikan hasil langsung terkait permasalahan perebutan lahan akan menjadi data pendukung.

Setelah data terkumpul, selanjutnya diolah ke dalam sejumlah kategori berdasarkan kerangka konseptual yang digunakan. Keterkaitan antar informasi digunakan untuk menemukan momen kunci dimana asal mula ditemukan candi, bagaimana terjadi konflik, bentuk penyelesaian konflik, serta kekuatan antar pihak yang berkonflik.

\section{Hasil dan Pembahasan}

Untuk menjelaskan mengapa lahan di kawasan situs bersejarah dapat menyebabkan timbulnya konflik yang berkepanjangan, terlebih dahulu diuraikan kronologi timbulnya konflik untuk menunjukkan akar masalah di balik perebutan klaim atas lahan situs tersebut. Selanjutnya, data tersebut akan dianalisis untuk men-jelaskan mengapa konflik berlangsung secara berkepanjangan.

Penemuan Situs Candi Bojongmenje bisa dikatakan terjadi tanpa sengaja. Berdasarkan penuturan informan, Ahmad dalam wawancara pada tanggal 14 Oktober 2016, penemuan situs itu bermula ketika pada tanggal 18 Agustus 2002, seorang warga setempat tengah menghabiskan waktunya untuk istirahat selepas pulang bekerja di lokasi pemakaman yang juga bertepatan dengan lokasi candi sebelum ditemukan. Informan menarasikan kejadian saat itu sebagai berikut: 
"Suatu ketika, warga setempat melihat seorang pria terpeleset, di jalan yang menjadi akses lintas pejalan kaki. Jalan tersebut memang kondisinya masih berupa tanah liat dan juga sempit. Karena kejadian tersebut, sekelompok warga kemudian berinisiatif untuk memperbaiki jalan tersebut. Ketika proses perbaikan jalan berlangsung, salah satu galian mengenai sebuah bongkahan batu. Warga yang melihat penemuan batu tersebut kaget karena setelah diamati batu tersebut berbentuk persegi dan tersusun kedalam hingga tingginya mencapai 30-40 $\mathrm{cm}$ pada kedalaman $50 \mathrm{~cm}$ dari permukaan tanah. Batu tersebut berbentuk persegi dengan posisinya yang tersusun kedalam tanah. Penggalian terus dilanjutkan dengan tambahan tenaga mencapai 6 orang hingga berakir pada pukul 17.00 dengan hasil penggalian mencapai kedalaman $130 \mathrm{~cm}$ serta berhasil menemukan 7 batu yang tersusun. Akhirnya, warga memutuskan untuk memberhentikan penggalian karena mereka merasa penemuan ini harus dikaji oleh pihak yang berwenang”.

Semenjak 2-3 hari setelah penemuan, Balai Arkeologi Bandung kemudian melakukan penggalian (ekskavasi) total selama 1 bulan. Dari ekskavasi tersebut ditemukan bagian kaki candi yang diketahui sebagai denah Candi Bojongmenje. Denah candi ditemukan di sisi barat dengan ukuran 7,04 m, sedangkan di sisi selatan 6,94 m. Sementara, struktur sisi utara belum tuntas diekskavasi karena lahannya menyatu dengan dinding pabrik. Pada bagian kakinya terlihat profil candi, sebuah perpaduan antara bingkai padma dan bingkai persegi, dan bagian setengah lingkaran. Profil candi itu menunjukkan bahwa candi tersebut berlatar belakang agama Hindu yang usianya diperkirakan berasal pada abad ke-7 Masehi. Hal ini diperkuat dengan ditemukannya beberapa fragmen arca, salah satunya adalah arca nandi yang berbentuk sapi jantan sebagai simbol kendaraan Dewa Siwa.
Penemuan ini menjadi sorotan banyak pihak ditambah peranan media baik televisi mapun radio yang membicarakan penemuan candi di Bojongmenje, sehingga menambah rasa penasaran masyarakat. Publik mengira di Bojongmenje telah ditemukan sebuah harta karun. Banyak orang berdatangan baik dari masyarakat lokal sampai manca-negara seperti India, Jepang, dan Belanda. Bahkan, berdasarkan wawancara dengan warga setempat, animo tersebut dimanfaatkan masyarakat Bojongmenje dengan berdagang tiket, brosur, jasa foto dan meraup keuntungan hingga 5 juta rupiah dalam satu hari.

Menurut penelitian arkeologi, Candi Bojongmenje merupakan suatu tempat yang difungsikan sebagai pertemuan antara dewa di langit dengan mahluk yang ada di dunia. Candi Bojongmenje merupakan tempat pendermaan tokoh raja atau apapun sesuai tingkatannya. Pendermaan ini menghadirkan roh pemimpin dan dewa untuk dikomunikasikan dan dipertemukan secara langsung. Selain itu, ditemukan pula pripeh yaitu batuan yang berbentuk kubus dan terbuat dari batu tufaan yang digunakan sebagai jimat dan dimiliki oleh raja. Temuan lainnya ialah puncak candi dan dinding bagian atas candi. Berbagai temuan itu mengindikasikan bahwa sebetulnya candi itu utuh. Untuk membedakan yang utuh atau tidak ialah dengan melihat bagian bawahnya yang terbuat dari batu dan puncaknya terbuat dari batu pula, sedangkan yang tidak utuh biasanya bagian kaki terbuat dari batu dan bagian puncaknya terbuat dari kayu.

Masyarakat yang diduga hidup pada zaman Candi Bojongmenje adalah masyarakat tani. Hal itu dibuktikan dengan ditemukannya telapak kaki anjing dan pecahan gerabah yang juga bisa berfungsi sebagai alat ritual serta terdapat tungku-tungku bekas. Namun, belum terbukti dari kerajaan apa Candi Bojongmenje itu berasal karena belum ditemukan sebuah prasasti guna menunjukan dari mana asal usul Candi Bojongmenje (Saptono, 2016). 
Aktivitas penggalian arkeologi yang berlangsung di sekitar situs candi mulai mengubah nilai tanah di kawasan tersebut. Banyaknya kunjungan masyarakat dari berbagai tempat ke sana mulai berdampak pada perubahan aktivitas perekonomian di kalangan masyarakat setempat. Perubahan nilai ekonomi lahan di sekitar situs memunculkan persaingan di antara warga setempat untuk memperoleh manfaat yang lebih besar dari lahan yang mereka miliki. Kondisi ini yang menurut pendapat Diehl \& Goertz (1993) rentan untuk memicu konflik pelik karena muncul situasi persaingan dominasi atas suatu sumber daya. Muncul relasi kekuasaan baru yang semula tidak ada ketika ada nilai tambah terhadap lahan akibat dari ditemukannya situs candi di sana. Para aktor yang menemukan situs memperoleh posisi kekuasaan yang lebih tinggi karena punya akses yang lebih luas untuk berkomunikasi dengan pihak luar desa (pemerintah dan arkeolog), sehingga melalui kontak dengan pihak luar desa tersebut, para penemu situs memiliki pengaruh lebih besar dalam menentukan bagaimana lahan sekitar situs akan dimanfaatkan.

Kemunculan aktor-aktor lain dari luar desa menambah kompleksitas pengelolaan lahan sekitar situs, terutama ketika pemerintah kemudian masuk ke dalam setting kasus. Untuk kepentingan pengembangan wisata di kawasan Situs Candi Bojongmenje, pemerintah membentuk tim pembebasan lahan. Tim ini bertugas mengurus pembebasan lahan sampai mensertifikasikan tanah tersebut agar dimiliki oleh pemerintah. Langkah pertama adalah pembebasan lahan seluas $845 \mathrm{~m}^{2}$ yang merupakan kepunyaan keluarga Anen Zulkarnaen menurut hasil girik (letter-c). Tetapi masyarakat dan kepala desa saat itu menuturkan bahwa tanah tersebut sudah menjadi pemakaman umum karena sudah diwakafkan oleh orang tua Anen. Akhirnya, tim pembebasan memutuskan untuk mengganti rugi dan akan membagi dua untuk ganti ruginya yaitu, lahan seluas $532 \mathrm{~m}^{2}$ yang sudah menjadi pemakaman umum dengan lahan seluas 313 $\mathrm{m}^{2}$ yang merupakan lahan kosong.
Setelah ada keputusan, tim pembebasan lahan memprioritaskan membebaskan tiap kuburan terlebih dahulu atau lahan yang sudah menjadi pemakaman umum. Lalu, dibuat perjanjian dalam permusyawaratan mengenai ganti rugi bagi pemilik lahan kubur. Awalnya pemerintah memberikan opsi untuk memindahkan jenazah-jenazah ke tempat baru yang nantinya disediakan, tetapi masyarakat memilih uang sebagai ganti rugi yang sudah sekaligus biaya pemindahan makam. Besaran harga ganti rugi ditetapkan berdasarkan harga tanah sesuai dengan Nilai Jual Obyek Pajak Bumi dan Bangunan (NJOP) tahun 2003 dari tanah yang bersangkutan (Sunarto, 2016).

Demikian masalah pembebasan lahan dengan para ahli waris telah selesai. Selanjutnya, pemerintah harus membebaskan lahan berikutnya guna perencanaan pengembangan Situs Candi Bojongmenje yaitu lahan seluas $313 \mathrm{~m}^{2}$ yang diklaim oleh Anen Zulkarnaen dan lahan pabrik sekitar candi. Sudah dijelaskan sebelumnya bahwa kepemilikan tanah yang dimiliki Anen tidak mempunyai sertifikat tanah resmi alias girik serta masyarakat pun mengetahui bahwa tanah yang diklaim tersebut sudah diwakafkan menjadi pemakaman umum. Anen Zulkarnaen sendiri menurut tim pembebasan lahan mengetahui bahwa tanah seluas $532 \mathrm{~m}^{2}$ milik para warga sudah dibebaskan tetapi ia tidak memberi harga yang sama untuk tanah yang diklaim olehnya. Ia memberikan harga Rp. $1.500 .000 / \mathrm{m}^{2}$. Harga yang ditawarkan Anen tentu sangat jauh dari NJOP tanah Bojongmenje pada tahun 2003 sekitar Rp. $64.000 / \mathrm{m}^{2}$. Oleh karena harga yang terlalu tinggi, pemerintah tidak bisa menyetujui karenadapat merusak harga tanah juga menjadi kecemburuan sosial bagi masyarakat yang lahan yang sebelumnya sudah dibebaskan. Ketidaksepakatan inilah yang kemudian memicu konflik. Masing-masing pihak saling mempertahankan pendapatnya masingmasing. Pemerintah ingin membebaskan lahan, tetapi dengan harga jual sesuai NJOP pada tahun 2003, sedangkan Anen ingin tanahnya terjual dengan harga yang sudah diminta (Nurhayati, 2016). 
Pemerintah beranggapan bahwa di atas lahan yang diklaim Anen tidak akan tinggi harganya bahkan melewati batas NJOP, karena aksesnya yang sulit untuk dijangkau dan daerahnya diapit oleh pabrik sehingga dengan harga yang diminta Anen sungguh tidak rasional (Suyantoro, 2016). Selain itu, pemerintah sudah melakukan negosiasi berkalikali dengan Anen, tetapi tidak berhasil mencapai kesepakatan. Modus Anen untuk mempertahankan lahan karena keinginannya untuk mendapatkan uang yang melimpah dari penjualan lahan jika pemerintah mau menuruti harga yang dimintanya (Suyantoro, 2016).

Berlarut-larutnya penyelesaian sengketa tersebut juga disebabkan oleh lemahnya posisi tawar pemerintah karena pemerintah tidak memiliki bukti bahwa tanah tersebut telah diwakafkan oleh keluarga Anen. Bukti tertulis berupa letter-c juga masih berada di tangan Anen, sehingga secara yuridis kedudukan Anen menjadi lebih kuat. Karena pemerintah tidak memiliki cukup bukti untuk melawan klaim Anen, maka pemberian ganti rugi dipilih sebagai bentuk kompromi antara pemerintah dan Anen.Tapi dalam negosiasi ganti rugi itu justru dimanfaatkan oleh Anen. Anen melihat kalau tanah tersebut adalah tanah berharga. Anen yakin bahwa pemerintah membutuhkan situs tersebut, sehingga pemerintah pasti akan membayar berapapun harga yang diminta olehnya. Untuk memperkuat posisi tawarnya, informan mengatakan bahwa Anen mempengaruhi warga lain untuk meminta ganti rugi dengan harga yang sama seperti Anen (wawancara dengan Ahmad, 2016). Ahmad (2016) juga mengatakan bahwa selain itu, Anen juga berkata bahwa dirinya merasa disepelekan jika ada pihak pemerintah yang sampai saat ini selalu menawar harga berdasarkan NJOP, menurutnya harga yang sudah ditetapkan olehnya adalah suatu bentuk perlawanannya terhadap pemerintah. Bahkan, harga yang dituntut oleh Anen sekarang sudah jauh lebih tinggi yaitu mencapai Rp 25.000.000/14m², sehingga, jika dihitung dari $313 \mathrm{~m}^{2}$ akan diperoleh sekitar 550 juta-an (Ahmad, 2016).
Sampai saat ini permasalahan pembebasan lahan Anen belum juga selesai, bahkan persoalan makin bertambah karena pihak pabrik turut menolak melepasan lahannya selama permintaan Anen belum dipenuhi oleh pemerintah tetapi memungkinkan jika lahan pabrik digunakan untuk kepentingan penelitian candi (Efendi, 2016). Menariknya, pemerintah tidak bisa berbuat apa-apa dalam masalah ini dan hanya mengandalkan negosiasi ganti rugi yang terhenti dengan Anen Zulkarnaen. Padahal bisa saja pemerintah membawa kasus ini ke ranah peradilan karena menurut UU Cagar Budaya tahun 2010 pada bab XI pasal 104 tercantum bahwa setiap orang yang dengan sengaja mencegah, menghalang-halangi, atau menggagalkan upaya Pelestarian Cagar Budaya dipidana dengan pidana penjara paling lama 5 (lima) tahun dan/atau denda paling sedikit Rp10.000.000,00 (sepuluh juta rupiah) dan paling banyak Rp500.000.000,00 (lima ratus juta rupiah). Pemerintah tidak dapat menggunakan ketentuan tersebut karena lahan di kawasan Situs Candi Bojongmenje belum secara resmi dinyatakan sebagai cagar budaya dan kategorinya masih merupakan situs arkeologi. Suatu kawasan dapat dinyatakan sebagai cagar budaya setelah melewati proses penetapan oleh tim ahli yang terverifikasi, sementara proses tersebut belum ditempuh oleh pemerintah.

Pada sisi lain, upaya penyelesaian secara hukum melalui pengadilan untuk membuktikan bahwa Anen menghalangi upaya pelestarian pun sulit dilakukan karena sebelumnya pemerintah sudah setuju menggunakan cara negosiasi ganti rugi kepemilikan lahan. Akibatnya, hingga sekarang pemerintah tidak dapat menindaklanjuti per-masalahan di Bojongmenje.

Kompleksitas permasalahan dalam pengelolaan lahan situs Candi Bojongmenje menjadi akar masalah yang menyebabkan konflik berkepanjangan antara pemerintah dan Anen, seorang warga setempat. Dalam sejumlah kasus konflik agraria, pemerintah biasanya menjadi pihak yang dominan dalam perebutan hak atas sumber agraria, tetapi dalam kasus Bojongmenje, pemerintah justru 
menjadi pihak yang posisi tawarnya lemah. Ketidakmampuan pemerintah menggunakan otoritasnya untuk menyeimbangkan relasi kekuasaan menyebabkan dampak konflik menyebar ke dalam arena lainnya, tidak hanya menghambat proses ganti rugi, memicu munculnya resistensi dari warga lainnya, bahkan juga menyebabkan pemugaran kawasan situs menjadi mangkrak. Terhentinya proses pemugaran situs menimbulkan ketidakpastian bagi warga setempat berkenaan dengan status kepemilikan atas lahan tersebut dan juga penggunaan lahan tersebut di masa mendatang.

\section{Simpulan}

Konflik lahan di kawasan situs Candi Bojongmenje merupakan bentuk konflik pelik, yang diawali oleh perubahan nilai ekonomi lahan akibat ditemukannya situs cagar budaya yang berpotensi wisata. Lahan yang semula tidak memiliki nilai jual, bahkan hanya dipergunakan sebagai tempat pemakaman umum, tetiba berubah menjadi kawasan potensial bagi wisata arkeologi. Perubahan tersebut menimbulkan ketidakstabilan sistem yang sebelumnya dianggap telah mapan, yakni sistem yang berkenaan dengan pemanfaatan lahan dan siapa yang berkuasa atas pemanfaatan lahan tersebut. Dalam struktur sosial yang semula, para tokoh pemimpin desa menjadi aktor utama yang menentukan penggunaan lahan tersebut. Tetapi, ketika lahan tersebut berubah memiliki nilai ekonomi, terjadi perubahan relasi kekuasaan. Muncul aktoraktor baru yang turut memiliki hak akses untuk menentukan penggunaan lahan, yakni warga setempat yang menemukan kawasan situs dan warga yang memiliki lahan di sekitar kawasan situs.

Konflik pelik ini berlangsung berkepanjangan dan tidak terselesaikan karena posisi tawar pemerintah sebagai institusi yang memegang otoritas justru berada pada posisi yang lemah. Pemerintah tidak memiliki bukti legalitas untuk menentukan pemanfaatan dan pengelolaan lahan situs. Regulasi justru menjadi penyebab lemahnya posisi tawar pemerintah, padahal regulasi adalah instrumen kekuasaan pemerintah. Riset ini menemukan bahwa lemahnya posisi tawar pemerintah menye-babkan akar konflik tidak terselesaikan, bahkan konflik menjadi menyebar ke arena baru, yakni resistensi dari warga setempat dan terhentinya proyek pemugaran lahan situs. Status quo dalam pengelolaan kawasan situs juga berdampak pada ketidakstabilan yang mengganggu kepentingan publik. Perubahan nilai ekonomi lahan yang kemudian terputus karena kawasan wisata tidak jadi dibentuk menimbulkan ketidakpastian bagi warga setempat berkenaan dengan status kepemilikan lahan dan pemanfaatannya.

Penyelesaian konflik pelik perlu dilakukan secara komprehensif, terutama untuk menyelesaikan akar permasalahan yang dipicu akibat dari ketidakstabilan perubahan. Pendekatan ganti rugi yang digunakan pemerintah untuk menyelesaikan konflik menjadi kurang relevan untuk menuntaskan konflik pelik. Penyelesaian konflik pelik perlu dilakukan dengan menyeimbangkan posisi kekuasaan dari para aktor yang berkepentingan di dalam pengelolaan lahan situs Candi Bojongmenje, yang diawali dengan pengakuan hak atas tanah dari warga setempat oleh pemerintah dan membangun kesepakatan dengan warga mengenai rencana pengelolaan kawasan tersebut secara partisipatif. Selain itu, penyelesaian konflik juga harus ditempuh melalui jalur hukum dengan mengacu pada ketentuan Undang-Undang Cagar Budaya tahun 2010.

\section{Daftar Pustaka}

Azar, E. E. (1990). The Management of Protracted Social Conflict. Hampshire, U.K. : Dartmouth.

Bocock, R. (1986). Hegemony. Chichester: Ellis Horwood Limited.

Burton, J. (1987). Resolving Deep-Rooted Conflict: A Handbook. Lanham: Md.: University Press of America.

Coleman, P. T. (2003). Characteristic of Prottacted, Intractable Conflict: Towards the Developement of Meta-Framework. Peace 
and Conflict: Journal of Peace Psychology , 197-235.

Deutsch, M. (1973). The Resolution of Conflict: Constructive and Destructive Processes. New Heaven: Conn.: Yale University Press.

Deutsch, M., Coleman, P. T., \& Marcus, E. C. (2006). The Handbook of Conflict Resolution: Theory and Practice. Josey Bass, A Wiley Brand.

Goertz, G., \& Diehl, P. F. (1993). Enduring Rivalries: Theoritical Constructs and Empirical Patterns.

Gramsci, A. (1973). The Prison Notebooks. New York: Columbia University Press.

Heryanto, A. (1997). "Hegemoni Kekuasaan Versi Gramsci". Forum Keadilan, 2(6).

Maftuchin, Annise Sri. (2016). "Tuan Tanah dan Lurah: Relasi Politik Lokal Patron-Cllient di Desa Sukorejo Kecamatan Godanglegi Kabupaten Malang dalam Kurun Waktu 2007-2013. Umbara 1(2), Desember. Hal. 138-149.

Maring, P. (2013). Kekuasaan dan Konflik Sosial: Kasus Penguasaan Hutan Noge di Tanaloran Flores. INSANI , 5.

Orr, E., Sagi, S., \& Bar-On, D. (2000). "Social Representations in Use: Israeli and Palestinian High School Students' Collective Coping and Defense". Social Representations , 9. Hal. 2.1-2.20.

Pruitt, D., \& Olczak, P. (2004). Beyond Hope: Approaches to Resolving Seemingly Intractable Conflict. Thousand Oaks, California: Sage.

Rouhana, N., \& Bar-Tal, D. (1998). "Psychological Dynamics of Intractable Conflicts: The Israeli Palestinian Case".American Psychologist. Vol. 53(7). Hal. 761-770.

Scott, J.C. (1981). Moral Ekonomi Petani: Pergolakan dan Subsistensi di Asia Tenggara. Jakarta: LP3ES.

Setiawan, F. N. (2016). "Hegemoni dan Dominasi Perusahaan Semen Terhadap Penduduk di Wilayah Pembangunan Pabrik Semen dalam Samin Vs Semen". EJournal Universitas Muhammadiyah Semarang .

Sobari, N., et al. (2012). Studi Teknis Candi Bojongmenje. Bandung: Balai Kepurbakalaan Sejarah dan Nilai Tradisional Disparbud Jawa Barat.

Sunarto, E., \& Daryat. (2003). "Berita Acara: Musyawarah Penetapan Besarnya Ganti Rugi/Transaksi Harga Tanah untuk
Kepentingan Kegiatan Pembinaan dan Pelestarian Peninggalan Sejarah dan Purbakala Jawa Barat Tahun Anggaran 2003 Berdasarkan SK Gubernur 910/kep.189-Dalprog/2003".

Wahyu, A. S., \& Kiptiah, M. (2016). "Identifikasi Konflik Perebutan Tanah Adat di Daerah Lahan Basah Kabupaten Banjar". Jurnal Ilmiah Pendidikan Pancasila dan Kewarganegaraan, Vol. 1(1). Hal. 1-6.

\section{Wawancara:}

Ahmad. (2016, Oktober 14).

Efendi. (2016, Oktober 25).

Nurhayati. (2016, Oktober 28)

Sunarto, E. (2016, November 11).

Suyantoro, K. (2016, November 4). 